\title{
Geological Aspect to Enhance Cultural Heritage at Ngempon Temple Geotourism Site, Semarang Regency, Central Java
}

\author{
Mohamad Fajril Falah ${ }^{1 *}$, Jenian Marin ${ }^{1}$, and Tri Winarno ${ }^{1}$ \\ ${ }^{1}$ Department of Geological Engineering, Diponegoro University, Semarang, Indonesia
}

\begin{abstract}
Ngempon Temple is one of the historical sites around the Mount Ungaran area. Ngempon Temple is the result of Hindu civilization in Indonesia which was built in the VIII-IX century. This research was conducted in the Ngempon area because it is necessary to conserve historical sites associated with geological sites in the study area. This study aims to determine the geological aspects that have the potential to become geotourism sites in the research area. The methods used are geological mapping for field data collection and petrographic analysis to determine rock characteristics. There are several sites including historical sites and geological sites in the vicinity of Ngempon Temple, namely Ngempon Temple, Diwak Waterfall, and Derekan Hot Springs. The lithologies found in the research area are claystone, tuff sandstone, basaltic andesite breccia, and andesite breccia. The volcanic rock in the research area is formed by Mount Ungaran activity during Lower Pleistocene until Holocene.
\end{abstract}

\section{Introduction}

Temple is a term that refers to a religious building where ancient relics of worship originate from the Hindu-Buddhist civilization. Ngempon Temple is one of the temples in Semarang Regency, which is located in Ngempon Village, Bergas District, Semarang Regency. The historical background of the construction of Ngempon Temple is not certain. Based on the architectural characteristics of the building, Ngempon Temple was built in the VIII-IX centuries, which has a Hindu background [1]

The position of Ngempon Temple, which is in the Ungaran Volcano area, and geological research, carried out in the Ngempon Temple area and its surroundings can be correlated with the distribution of rocks in the Ngempon Temple area with the volcanic facies [2]. These volcanic facies provide an overview of the distribution of rocks found in the area around the volcano and, as information, support determining the characteristics and rock genesis in the Ngempon Temple area. This research was conducted in the Ngempon area because it is necessary to conserve historical sites associated with geological sites in the research area. This study aims to determine the geological aspects that have the potential to become a geotourism site in the research area.

\footnotetext{
* Corresponding author: fajrilfalah135@gmail.com
} 


\section{Regional geology}

Based on geology map of Magelang Semarang [3] as shown in (Fig. 1). The stratigraphy of research area is as follows:

1. Gajahmungkur Volcanic Rocks (Qhg), the rocks are andesite lava with gray-colored, fine-grained, holocrystalline, the mineral composition is feldspar, hornblende and augite, the rock is hard and compact. It locally shows a sheeting joint structure.

2. Kaligetas Formation (Qpkg), the rocks are breccias and lava with fine to coarse lava and tuff inserts. Mudstone that contains mollusks and tuff sandstone are found locally at the bottom.

3. Kerek Formation (Tmk), interchange of clay stones, marl, tuffaceous sandstones, conglomerates, volcanic breccias, and limestones.

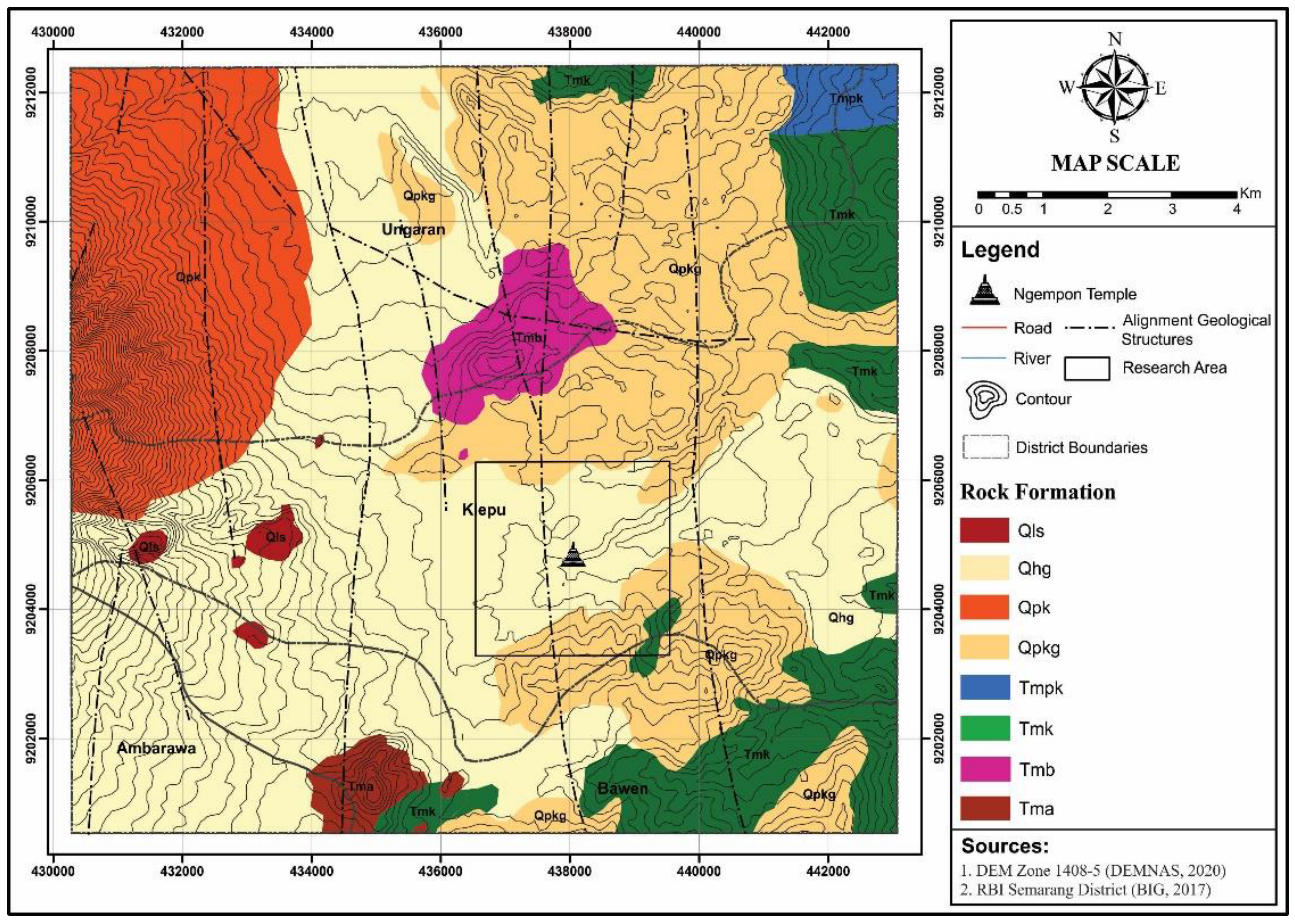

Fig. 1. Geological Map of research area located in Semarang Regency, Central Java (Thanden et al, 1996).

\section{Research Methodology}

The stages of this research were carried out in four steps: literature study, collecting data, processing, data interpretation, and report preparation. Primary data in this study were obtained from data collection in the field. Geological data collection includes determining lithology, measuring geological structures, and taking rock samples for laboratory analysis. Laboratory analysis was conducted with petrographic analysis. This analysis is carried out on rock samples that have been taken from the field to obtain more detailed data. The laboratory analysis carried out was a petrographic analysis using a polarizing microscope. This analysis was carried out on five thin section samples from the results of sampling in the field. Secondary data in this study are location maps and topographic maps of the research area. The purpose of making this map is that in collecting data in the field, the 
researcher knows the boundaries of the area and the topographical conditions of the research area.

Processing and interpretation of data are carried out from the data collection results in the field and laboratory analysis. The results of processing and interpretation of this data will produce a geological map and a geomorphological map of the research area. Then, the interpretation of the genesis and volcanic facies in the research area was carried out from the results of geological and geomorphological maps as well as satellite image data in the form of DEM data.

\section{Result and Discussion}

\subsection{Geological Features of the Ngempon Temple Area}

The The Ngempon Temple area includes the villages of Ngempon, Diwak and Derekan. Based on architectural features and the discovery of statues with Hindu characteristics, it can be seen that Ngempon Temple is a cultural heritage from the era of Hindu civilization in Indonesia. According to local community sources, this temple used to be a training centre for masters in practising kanuragan, literature and spirituality. There is very little explanation about this temple, but it still has an architecture similar to Gedongsongo Temple, which has a characteristic Central Javanese style of architecture [4]. The Ngempon Temple site consists of 4 reconstructed temple buildings and several temple foundations that have not been reconstructed.

Around the Ngempon Temple Area, several sites include historical sites and geological sites (Fig 2). Historical sites are in Ngempon Temple, while geological sites form Diwak Waterfall and Derekan Hot Springs. In addition, travertine layers were also found in the Ngempon Temple Area. The travertine layer in the research area was only found around the location of the manifestation, which is still active in the form of a hot spring in Derekan Village. Travertin is part of terrestrial or terrestrial carbonate sedimentary rocks formed by the deposition or precipitation of carbonate minerals from soil and surface water solutions and heating from hot springs [5]. Derekan hot spring is located in Derekan Village and is close to the Ngempon Temple site. These hydrothermal fluids manifestations emerge to the surface through porous zone like cracks [10]. The waterfall is located in Diwak Village, and this waterfall has a height of $\pm 3 \mathrm{~m}$ with the morphology of a very steep slope. Based on the appearance of regional morphology and geology, this waterfall is interpreted to be formed as a result of a fault structure; this interpretation is reinforced by the presence of geothermal manifestations of Derekan, which is not far from the location of this waterfall.

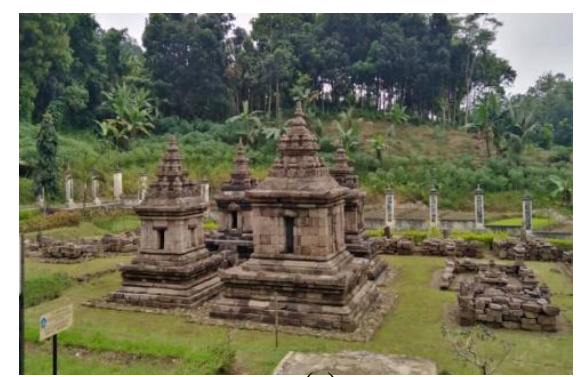

(a)

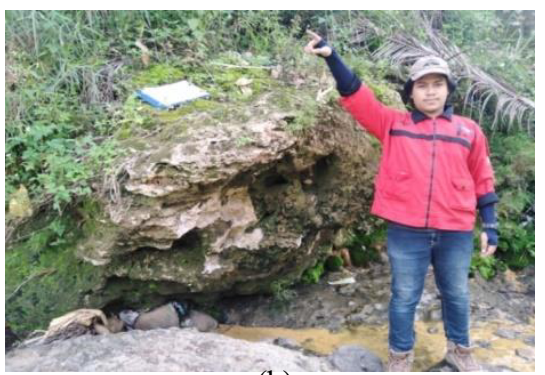

(b) 


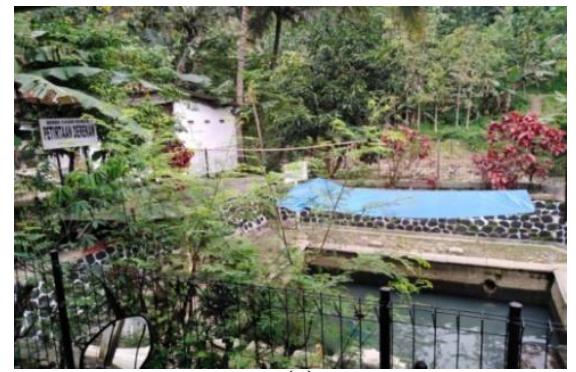

(c)

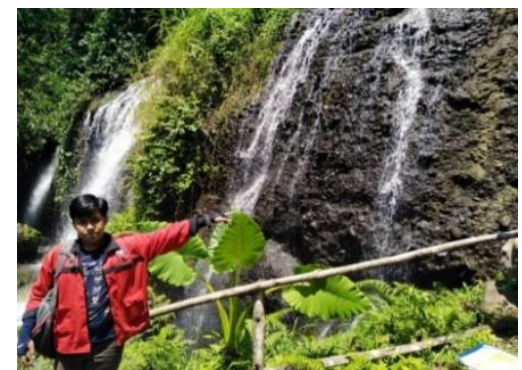

(d)

Fig. 2. (a) Ngempon Temple (b) Travertine layer (c) Derekan hot spring (d) Diwak waterfall.

\subsection{Geological condition of the research area}

The stratigraphic determination in the research area is based on field lithology data collection results then adjusted to the regional geology of the Magelang - Semarang sheet [3]. The results of lithology data collection in the field were then performed petrographic analysis on the sample of each lithological unit found so that the composition and name of the rock were known. Based on the results of data collection in the field and petrographic analysis, interpretation is carried out to determine the distribution of rocks in the research area, which is then displayed in the form of a geological map (Fig 3) and a geological cross-section (Fig 4).

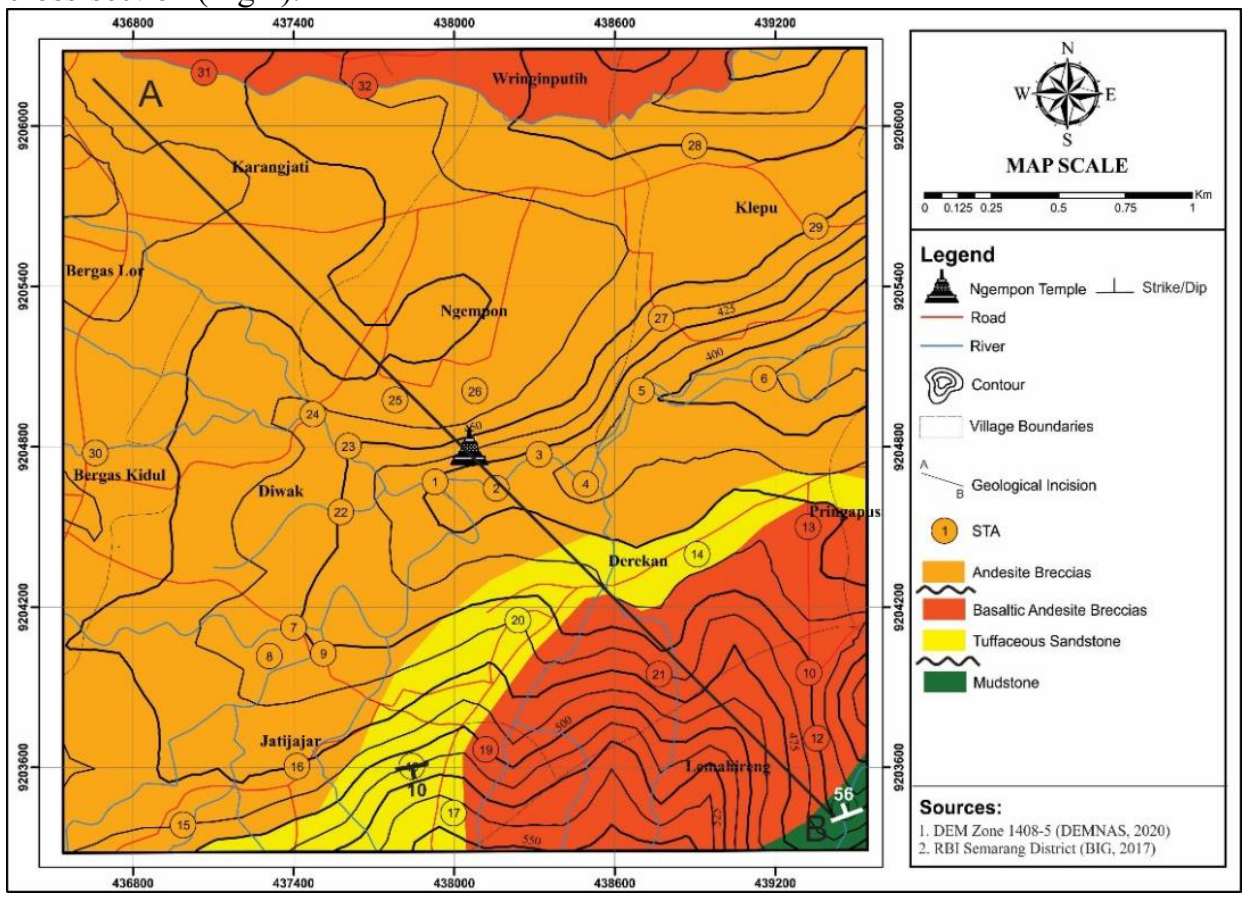

Fig. 3. Geological map of the research area. 


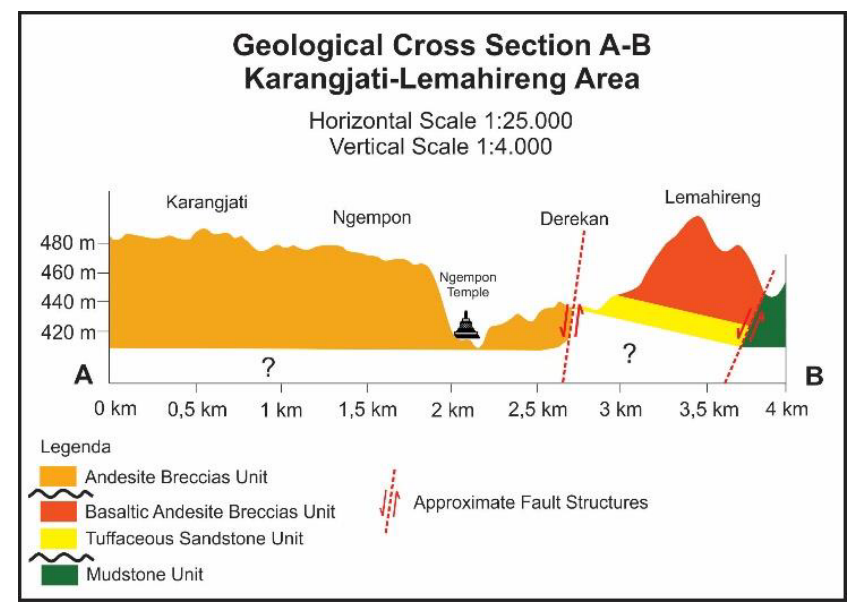

Fig. 4. Geological cross section of the research area.

1. Claystone unit (Kerek Formation)

Claystone units in the research area are found in Lemahireng Village. The outcrop appearance is grey and has a massive structure with medium-high weathered rock conditions. This rock has a very fine grain size of $\leq 1 / 256 \mathrm{~mm}$ with carbonic cement. On microscopic observation, it was found that the composition was in the form of clay minerals (Lp) 97\%, foraminifera fossils (Fs) 2\%, and opaque mineral (Op) 1\% (Fig 5).

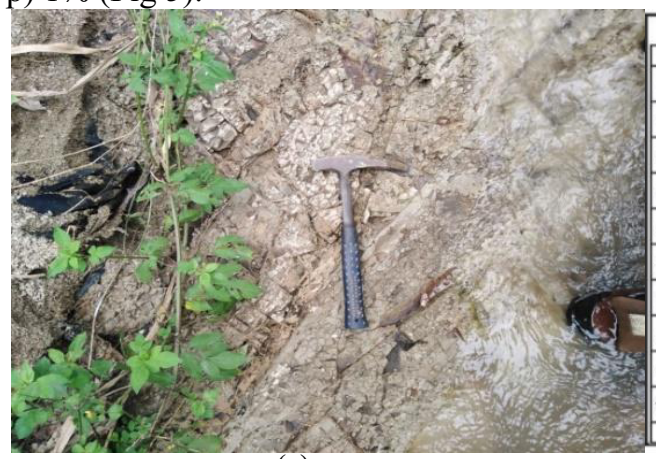

(a)

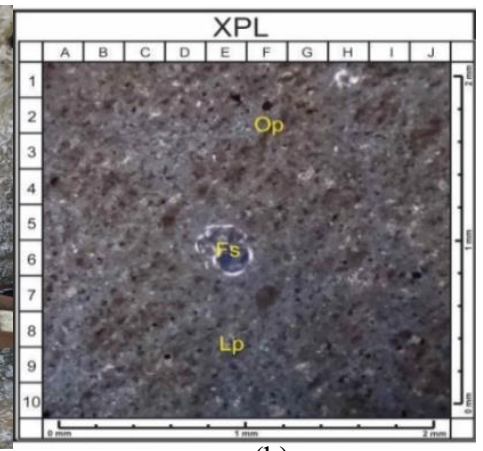

(b)

Fig. 5. (a) Claystone unit at STA 11 (b) Petrographic appearance (opaque minerals (Op), clay minerals (Lp), foraminifera fossils (Fs)).

2. Tuffaceous sandstone and basaltic-andesitic breccia unit (Kaligetas Formation)

This formation in the research area is found in Derekan Village. The tuffaceous sandstone unit has a fairly fine grain size of 1/8-1 / $4 \mathrm{~mm}$ with non-carbonic cement. In microscopic appearance, it is known that the mineral composition found in this thin section includes quartz $(\mathrm{Kw}) 1 \%$, feldspar (Fs) 1\%, opaque minerals (Op) 3\%, and volcanic glass (Gl) $95 \%$. While the composition of basaltic-andesitic breccia fragment was plagioclase minerals (Pl) Carlsbad-albite twin with An 66 value (labradorite) $35 \%$, quartz (Kw) $1 \%$, pyroxene (Pr) 20\%, opaque minerals (Op) $3 \%$, and the matrix (Ms) of this thin section is volcanic glass and has an abundance of $41 \%$ in the thin section (Fig 6). 


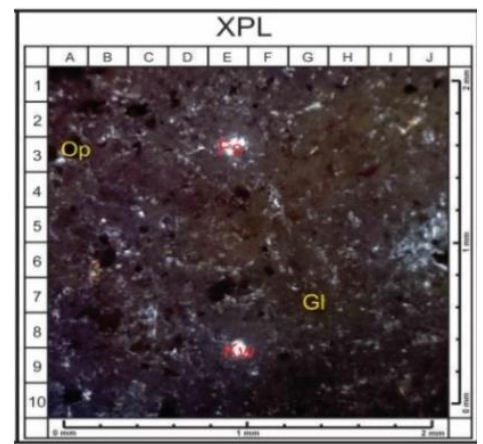

(a)

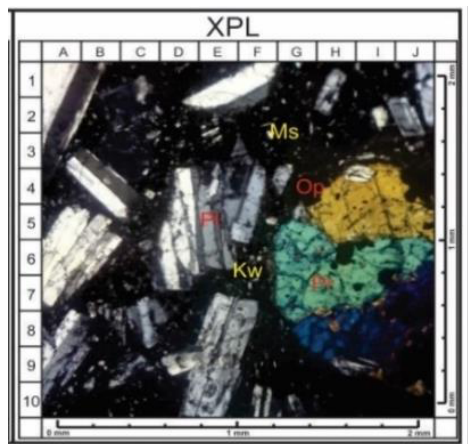

(b)

Fig. 6. (a) Petrographic appearance of tuffaceous sandstone (opaque minerals (Op), quartz (Kw), feldsapar (Fs), volcanic glass (Gl)) (b) Petrographic appearance of basaltic andesitic fragment (opaque minerals $(\mathrm{Op})$, quartz $(\mathrm{Kw})$, plagioclase $(\mathrm{Pl})$, pyroxene $(\mathrm{Pr})$, base mass $(\mathrm{Ms})$ ).

3. Andesitic breccia unit (Gajahmungkur Volcanic Rocks)

This lithology unit in the research area was found in Jatijajar, Bergas Kidul, Bergas Lor, Diwak, Karangjati, Ngempon and Klepu villages. This andesitic breccia unit is the rock unit that most dominates the research area. Based on the results of microscopic observations, the rock fragment mineral composition found in this thin section includes plagioclase minerals (Pl) which have a Carlsbad-albite twin with An 43 (andesine) 45\%, quartz (Kw) 1\%, pyroxene (Pr) 4\%, biotite (Bi) 12\%, opaque minerals (Op) 3\%, and base mass (Ms) 35\%. The matrix mineral composition includes quartz $(\mathrm{Kw}) 3 \%$, feldspar (Fs) 6\%, pyroxene (Pr) 3\%, opaque minerals (Op) $3 \%$, lithic fragments (Lt) consisting of quartz, feldspar, pyroxene, opaque minerals, and volcanic glass $45 \%$, and volcanic glass (Gl) $40 \%$ (Fig 7).

This lithology also found a joint structure. From the results of the measurement of the joint position, it was found that the joint structure pattern that developed at the research area had a NE-SW orientation direction.

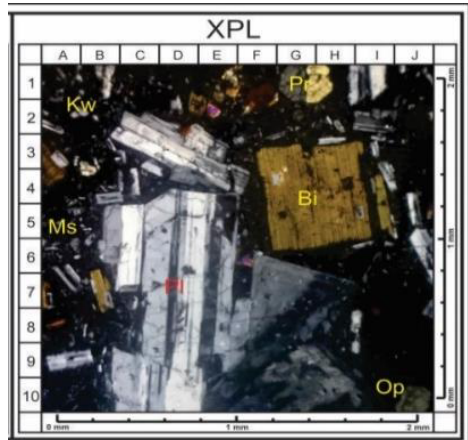

(a)

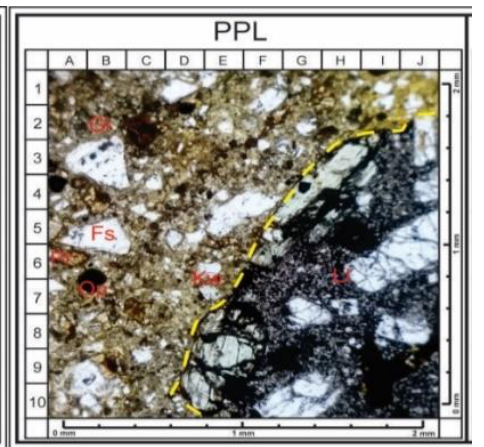

(b)

Fig. 7. (a) Petrographic appearance of andesitic breccia fragment (opaque minerals (Op), quartz (Kw), plagioclase $(\mathrm{Pl})$, pyroxene $(\mathrm{Pr})$, base mass $(\mathrm{Ms})$, biotite $(\mathrm{Bi}))(\mathrm{b})$ Petrographic appearance of andesite breccias matrix (opaque minerals $(\mathrm{Op})$, quartz $(\mathrm{Kw})$, pyroxene $(\mathrm{Pr})$, volcanic glass $(\mathrm{Gl})$, feldspar $(\mathrm{Fs})$, lithic fragment (Lt)).

\subsection{Volcanic facies in the research area}

The landforms found in the research area are two landforms, namely the volcanic mudflow plain and volcanic mudflow ridge [7]. The landforms in the research area are dominated by 
lithology originating from Ungaran Volcano material deposited by a volcanic mudflow mechanism. The lithology found in the two landforms in the research area is laharic breccias.

Based on the geomorphological observations of the research area, which is the flat foot of the volcano from Ungaran Volcano, and the lithology of the research area in the form of laharic breccias and tuffaceous sandstones, it can be interpreted that the research area is included in the medial facies of the Ungaran Volcano [2] [8] (Fig 8).

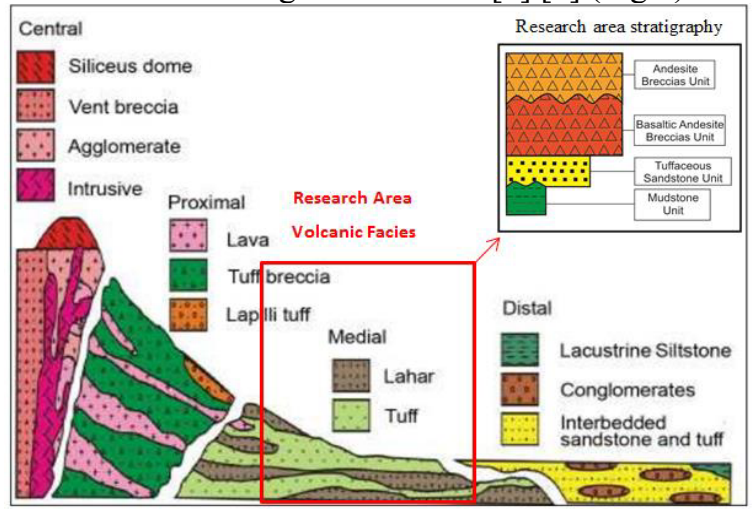

Fig. 8. Research area volcanic facies (Bogie and Mackenzie, 1998).

\subsection{Geological history of the research area}

Based on Thanden et al. (1996) [3] in the Lower Pleistocene Period ( \pm 2.5 million years ago), the Kaligetas Formation was deposited, which in the research area of this formation was in the form of andesitic basaltic breccia and tuffaceous sandstones. At this time also formed the Old Ungaran, where the products of Old Ungaran consist of pyroclastic flows, andesitic basaltic lava, and hornblende augite andesitic tuff [6]. After the deposition of the Kaligetas Formation in the lower Pleistocene, there was a long delay until finally the Gajahmungkur Formation was deposited in the research area in the form of andesitic breccias in the Holocene ( \pm 11,500 years ago) [3]. Young Ungaran was formed from the centre of Old Ungaran, which had previously been collapse and destroyed due to the deformation of the volcano-tectonic system [6]. From the observations in the field, the andesitic breccia which is included in the Gajahmungkur Formation is interpreted as a laharic breccia from the eruption of the Young Ungaran (Fig 9) [9].

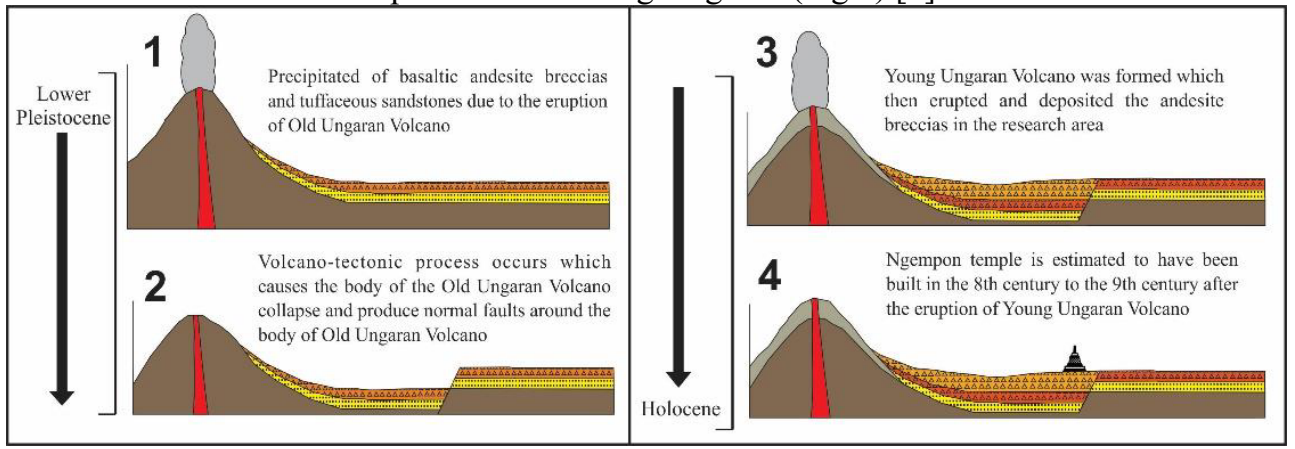

Fig. 9. Geologial history of the research area. 


\section{Conclution}

In the research area, several geological features have considerable geotourism potential and must be conserved, namely hot springs and waterfalls. The lithology of the research area consists of four lithological units, namely claystone, tuffaceous sandstones, basaltic andesite breccias, and andesite breccias.

Based on the geomorphological observations of the research area, which is the flat foot of the volcano from Ungaran Volcano and the lithology of the research area in the form of laharic breccias and tuffaceous sandstones, it can be interpreted that the research area is included in the medial facies of the Ungaran Volcano. The geological features in this research area were formed due to the activity of the Ungaran Volcano and geological activities in the past.

\section{References}

1. Badan Pelestarian Cagar Budaya Jawa Tengah, Candi Ngempon, Accessed on https://kebudayaan.kemdikbud.go.id/bpcbjateng/candi-ngempon/ at December 5, 2020, (2016)

2. Bogie, I., and Mackenzie, I. C. M., The application of a volcanic facies model to an andesitic stratovolcano hosted geothermal System At Wayang Windu, Java, In Indonesia Proceedings of New Zealand Geothermal Workshop, Auckland New Zealand, (1998)

3. Thanden, R. E., Sumadirdja, H., Richards, P. W., Sutisna, K., and Amin, T. C., Peta Geologi Lembar Magelang and Semarang skala 1(100.000), (1996)

4. Yuliati, D., Pelestarian Candi Ngempon and Pemanfaatannya untuk Atraksi Pariwisata. Anuva: Jurnal Kajian Budaya, Perpustakaan, and Informasi, 3 (3), 223231, (2019)

5. Pentecost, A., Travertine, Springer Science \& Business Media, (2005)

6. Hadisantono R.D., and Sumpena A.D., Laporan pemetaan daerah bahaya G.Ungaran and sekitarnya, Jawa Tengah, Proyek pengamatan/ pengawasan and pemetaan gunungapi, Departemen Pertambangan and Energi, Dir. Jend. Geologi Sumberdaya Mineral, Direktorat Volkanologi, Bandung, 26 page, (1993)

7. Brahmantyo, B., and Salim, B., Klasifikasi Bentuk Muka Bumi (Landform) untuk Pemetaan Geomorfologi pada Skala 1: 25.000 and Aplikasinya untuk Penataan Ruang, Jurnal Geoaplika, 1(2), 071-078, (2006)

8. Bronto, S., Fasies gunung api and aplikasinya, Indonesian Journal on Geoscience, 1(2), 59-71, (2006)

9. Marin, J., Studi Geomorfologi Gunung Api And Petrogenesa Batuan Untuk Memahami Evolusi Vulkanotektonik Pada Gunung Ungaran, Provinsi Jawa Tengah, In Proceeding, Seminar Nasional Kebumian Ke-8 Academia-Industry Linkage 15-16 Oktober 2015; Grha Sabha Pramana, Departmen Teknik Geologi, (2015)

10. Herlambang, Y. D., Harmoko, U., Widodo, A., Yulianto, G., Widada, S., and Sahid, S., Pembangkit Panas Bumi Kapasitas 2 Kw Memanfaatkan Sistem Enthalpi Rendah Untuk Aplikasi Sistem Off-Grid, Eksergi, 17(1), 67-75, (2021) 